Resenha: MACHADO, C. E. J.; MACHADO JR., R.; VEDDA, M. (Orgs.). Walter Benjamin. Experiência histórica e imagens dialéticas.

\title{
WALTER BENJAMIN
}

MACHADO, Carlos Eduardo Jordão; MACHADO JR., Rubens; VEDDA, Miguel (orgs.). Walter Benjamin. Experiência histórica e imagens dialéticas. São Paulo: Editora UNESP, 2015,455 p.

Vanessa Madrona Moreira Salles*

Walter Benjamin (1892-1940), filósofo, tradutor, ensaísta berlinense, frequentemente é apresentado como um pensador da "Escola de Frankfurt". Teve uma formação intelectual diversificada, em Universidades alemãs e suíças, estudando assuntos diversos: filosofia, literatura, história, psicologia, teatro, etc. O cenário histórico onde transcorre a existência desse autor é um palco em transformação. A sociedade europeia do século XIX, particularmente na Alemanha, caminha para o declínio da aristocracia e a consolidação da burguesia como força econômica, social e política. A importância dos fenômenos massivos se intensifica. E as duas grandes guerras mundiais são acontecimentos que alteraram profundamente a história da sociedade moderna. A vida desse ensaísta, que é forçado ao exílio devido a sua condição de judeu, logo que Hitler ascende ao poder na Alemanha, em 1933, será, portanto, marcada profundamente por esse contexto complexo e diverso da história mundial e sua obra resulta como um importante "documento" e "monumento" das grandes transformações históricas, políticas, culturais e sociais do século XX.

Publicada em 2015, a coletânea intitulada "Walter Benjamin. Experiência histórica e imagens dialéticas" destaca-se por nos apresentar uma grande diversidade de temas que se relacionam com conceitos benjaminianos, nos ensaios elaborados por pesquisadores provenientes de diversas áreas do conhecimento - filosofia, história, letras, educação, comunicação, etc. - e de instituições várias: programas de Pós-graduação da Universidade Estadual Paulista (UNESP), da Universidade de São Paulo (USP), da Universidade Estadual de Campinas (Unicamp), da Pontifícia Universidade Católica de São Paulo (PUC-SP), da Universidade Federal do ABC (UFABC), da Universidade de Buenos Aires, do Centre National de la Recherche Scientifique (CNRS), de Paris, do Benjamin-Archiv, de Berlim, da Universidade de Constança e da Universidade de Hildesheim, ambas alemãs, Universidade de Girona, da Espanha, e da Universidade de Budapeste (Hungria). A maioria dos ensaios foi

\footnotetext{
* Doutora em Filosofia/USP - Professora na Universidade FUMEC. E-mail: vanessasalles@uol.com.br.
} 
inicialmente apresentada no colóquio "Walter Benjamin e a questão da memória", realizado pelo Centro Haroldo Conti, em Buenos Aires, em 2010.

A publicação reúne trinta e quatro artigos em torno de cinco eixos: "Das Imagens da Memória ao Fetiche e suas Fantasmagorias"; "Passagens, Teoria da História e Revolução"; "Literatura, Música e Surrealismo"; "Melancolia, Brinquedo, Freud e Leituras" e "Cinema Alegoria e Imagens Urbanas”. O fio condutor desses eixos é o reconhecimento da atualidade do ensaísta e filósofo alemão, Walter Benjamin (1892-1940) “como crítico da cultura da modernidade incomum" (p.XIII).

Selecionamos em cada um dos cinco eixos, o primeiro artigo. A escolha se justifica como exemplificação de algumas das possibilidades de articulação de assuntos diversos com conceitos benjaminianos, em especial, o conceito de experiência histórica e o conceito de imagens dialéticas.

Na constelação "Das Imagens da Memória ao Fetiche e suas Fantasmagorias”, temos o artigo "Walter Benjamin - "Esquecer o Passado?", de Jeanne Marie Gagnebin (Unicamp e PUC-SP). A autora recorre a conceitos benjaminianos para problematizar um tema emblemático: a política de esquecimento que envolve a história recente brasileira relativa à ditadura militar de 1964 a 1985. Discute desde as implicações dos vocábulos utilizados no país, ao designar como "desaparecidos" e não como vítimas aqueles que foram torturados e assassinados nesse período, como a urgência de se elaborar "uma memória social e coletiva compartilhada por todos.” (p.7) E para efetivar esse resgate a autora sugere a retomada da proposição benjaminiana de que é necessário que haja uma historiografia que salve a memória dos vencidos e que aponte para outras "possibilidades de luta e de ação no presente" (p.7).

No capítulo "Passagens, Teoria da História e Revolução", Michael Löwy (diretor no CNRS, professor na EHESS) discorre sobre "A Cidade, lugar estratégico do enfrentamento das classes. Insurreições, barricadas e haussmannização de Paris nas Passagens, de Walter Benjamin", de maneira didática e esclarecedora. O articulista mostra que, para Benjamin, os ecos dos acontecimentos históricos e sociais da capital francesa no século XIX reverberam na Europa dos anos 1930. Os acontecimentos oitocentistas são agrupados em três momentos: a insurreição e as barricadas no período de 1830 a 1848; a reação burguesa que levou à reforma urbanística de Paris com evidentes interesses políticos de neutralizar a ação das massas, operada pelo barão Haussmann, (1860-1870), forma de "expressão do caráter autoritário e arbitrário do poder" (p. 76) e o terceiro, a Comuna de Paris, no ano de 1871. Para Löwy a posição ambígua do ensaísta alemão em sua avaliação dos acontecimentos parisienses em 
Resenha: MACHADO, C. E. J.; MACHADO JR., R.; VEDDA, M. (Orgs.). Walter Benjamin. Experiência histórica e imagens dialéticas.

1871, dever-se-ia a um "questionamento, certamente implícito e indireto, da política do PCF [Partido Comunista Francês] nessa época” (p.83) ${ }^{1}$. No entanto, conclui Löwy, destaca-se nesses apontamentos, a relevância dada ao papel revolucionário das mulheres, desde os levantes populares dos anos 1830-1848 à sua atuação nos acontecimentos da Comuna.

No eixo "Literatura, Música e Surrealismo", Gábor Gángó (Universidade Budapeste, Hungria) discorre sobre "O conto de fadas como esclarecimento, cultura e violência". Na Alemanha do período entreguerras vários autores retomaram esse assunto, dentre eles, Walter Benjamin, Siegfried Kracauer, Ernst Bloch e Theodor W. Adorno.

Walter Benjamin destacará o potencial emancipatório dos contos de fadas e os apresentará como antimitológicos. No entanto, o cerne desse artigo é mostrar que o tema dos contos de fadas fora tratado, em 1919, por Lukács como fenômeno que pertence "ao mundo das possibilidades radicalmente ampliadas" (p.174), e que os contos de fadas foram utilizados pelos políticos culturais da República Soviética da Hungria, como forma de preparação das crianças para a "redenção comunista" (p.179).

No penúltimo bloco, "Melancolia, Brinquedo, Freud e Leituras" temos o artigo de Toni Tholen (Universidade de Hildesheim) intitulado "Crítica melancólica - Benjamin e Adorno". Nesse texto o autor se propõe a esclarecer o que é a "crítica melancólica", proposta por Benjamin em "Origem do Drama Barroco Alemão" e a apropriação e modificação desse conceito por Adorno.

Finalmente, no quinto eixo "Cinema, Alegorias e Imagens urbanas", Ismail Xavier (ECA-USP) discorre sobre o filme Metropolis, de Fritz Lang (1927) em "A alegoria langiana de Babel e o Monumental: Metropolis e seu descompasso com a visão política da modernidade em Walter Benjamin”. Nesse instigante ensaio, Ismail recorre a um conceito caro a Benjamin - o conceito de alegoria - para mostrar como esse filme, efetivamente, apresenta o tempo da repetição do sempre igual, fazendo com que o presente e o futuro se posicionem numa circularidade mítica.

Todos esses artigos chamam a atenção para as peculiaridades do "método benjaminiano": a abertura para uma constelação de significados, complexa, dialética, plural; a indeterminação de fronteiras disciplinares, a fixação no fragmento, a escrita visual.

Os artigos reunidos nessa publicação apontam para várias facetas da obra benjaminiana. Alguns mostram a interlocução benjaminiana com seus contemporâneos, sejam estes filósofos, poetas, diretores de teatro, artistas, fotógrafos, ensaístas, romancistas, etc. Sua

\footnotetext{
${ }^{1}$ Os excertos das Passagens referentes à Comuna foram elaborados por Benjamin nos anos 1930.
} 
predileção por: Baudelaire, Kafka, Blanqui, o Surrealismo, Brecht, Proust, etc. Outros evidenciam o interesse de Walter Benjamin por temas desprezados pela tradição filosófica: objetos do cotidiano, como aqueles que compõem o interior das casas burguesas, as novas formas urbanas - as construções em ferro e vidro, a multidão, os bulevares, as passagens, a iluminação das ruas, etc. A infância - os contos de fadas, os brinquedos, a educação -, os dramas barrocos jamais encenados. As imagens feitas por máquinas: fotografia e cinema. Benjamin e sua tarefa como tradutor.

Em todos os artigos conceitos benjaminianos são configurados em novas constelações: a história a contrapelo, o tempo messiânico, a alegoria, as fantasmagorias, as imagens dialéticas, a memória, crítica à ideia de progresso, o inconsciente ótico, a crítica melancólica, a iluminação profana, etc. Sua consciência do tempo presente que o faz voltar ao passado para refletir sobre a possibilidade de influir na construção do futuro.

E, uma observação importante, esta coletânea, mais do que apresentar a riqueza e amplitude do pensamento de Walter Benjamim, deixa evidente a atualidade de seus conceitos para "iluminar" fenômenos e acontecimentos do "nosso" presente. 